Grzegorz Raubo

\title{
„Perspektywy gwiazdarskie”. Lunety w literaturze i piśmiennictwie naukowym polskiego baroku
}

Zastosowanie lunety do obserwacji astronomicznych odegrało istotną rolę w nowożytnej rewolucji naukowej. Rezultaty teleskopowych badań firmamentu przyczynily się do zmiany naukowego obrazu kosmosu i do stworzenia nowej, dotyczącej całego wszechświata wykładni zjawisk przyrodniczych, która unieważniała tradycyjny podział na obszar ziemski i obszar niebieski. Historyczne znaczenie teleskopu wykracza jednak poza sferę właściwą dla dziejów nauki. W okresie baroku to nowoczesne narzędzie poznawania nieba zajmowało również ważne miejsce w kulturze.

Luneta figuruje $w$ inwentarzach przedmiotów wypełniających wunderkamery, barokowe gabinety osobliwości. Pojawia się w nich w sąsiedztwie innych przyrządów astronomicznych, obok mikroskopów, globusów i termometrów, w otoczeniu pamiątek historycznych (posągów, medali, monet i rycin), obok niezwykłych przedmiotów z egzotycznych krajów, dzieł sztuki czy dziwów natury (rzadkich muszli, kości olbrzymów i okazów fantastycznej zoologii) [Pomian 1996: 65-66; Eco 2009: 204]. Ożywiająca ówczesne kolekcjonerstwo „kultura ciekawości” znajdowała miejsce dla lunet w gabinetach, których ikonografia 
inspirowana była kosmologią antyczną i średniowieczną, podważoną właśnie w efekcie użycia teleskopu do badania nieba [Pomian 1996: 95-96].

Wyniki tych badań były inspirujące dla sztuki, zwłaszcza dla malarstwa baroku. W niektórych obrazach prezentujących tematykę religijną doszukiwano się bowiem przedstawień Drogi Mlecznej przypominających jej obraz uzyskany dzięki lunecie, jak też ukazania tarczy Księżyca, zgodnego z wizerunkiem Srebrnego Globu prezentowanym w selenograficznych pracach astronomów [Włodarczyk 2012: 37-40].

Zaciekawienie lunetą uwidoczniło się w świecie przedstawionym literatury baroku. Wszechstronnie dokumentuje to literatura angielska, gdyż rezultaty teleskopowych obserwacji nieba i heliocentryzm były dla jej twórców jednymi z najważniejszych bodźców do formułowania fundamentalnych pytań dotyczących człowieka i kultury, którą odkrycia i teorie nowej astronomii postawiły wobec nieznanych wcześniej perspektyw i wyzwań poznawczych, wiążących się między innymi z potrzebą uzgodnienia nowej nauki z tradycyjną wrażliwością religijną. Literatura czerpiąca $\mathrm{z}$ astronomicznych nowości wydała utwory utopijne i dzieła w konwencji science fiction, prezentujące wizje kosmicznej podróży i zamieszkałego Srebrnego Globu. Nowoczesne obserwacje astronomiczne pobudzały inwencję satyryczną: w poemacie Samuela Buttlera Stoń na Księżycu, prześmiewczo przez poetę sportretowani członkowie Towarzystwa Królewskiego, oglądający ziemskiego satelitę przez teleskop, dostrzegają na nim słonia i walczących między sobą Selenitów. Okazuje się jednak, że zwierzę, brane przez nich za słonia, jest myszą zawieruszoną w tubusie, w którym znalazły się też owady, uznane przez uczonych za istoty zaludniające Księżyc [Hayden 2016]. Dobitnym poświadczeniem obecności lunety w kulturze literackiej epoki jest również to, że, potraktowana jako metafora, widnieje w tytule sławnego teoretycznego traktatu, Lunety Arystotelesowskiej Emmanuela Tesauro (1658) ${ }^{1}$. W jego ujęciu retoryczna teoria Stagiryty jest „najdoskonalszą lunetą do badania 
wszystkich doskonałości i niedoskonałości mowy”, a operujące arystotelesowskimi pojęciami dzieło włoskiego autora rekomenduje śmiałe, nowatorskie zasady barokowego konceptyzmu. Jego traktat, odsyłając do starożytnego autorytetu wiedzy o literaturze, a równocześnie z uznaniem mówiąc o holenderskim optyku Zachariaszu Janssenie, który „wzniósł wzrok ludzki tam, gdzie nie doleci ptak", w tytułowej formule trafnie oddaje ideową specyfikę barokowej teorii twórczości. Wyrastała ona z arystotelizmu, lecz kreowała nowy model sztuki: współbrzmiący z ideową atmosferą epoki, a więc też konweniujący ze zmianami w obrazie kosmosu, które wówczas się dokonywały [Gostyńska 1991: 18-19].

Zainteresowanie lunetą potwierdzają powstałe w Rzeczypospolitej źródła literackie oraz utwory piśmiennicze, obejmujące traktaty naukowe i popularne kompendia wiedzy. Mówiąc o efektach badań osiągniętych dzięki lunecie, pisarze i uczeni podnosili ich przełomowe znaczenie poznawcze, pozwalające na podjęcie polemiki z autorytetami nauki starożytnej, jak też postawienie pytań dotyczących systemu świata i koncepcji wielu światów. Obok fascynacji możliwościami widzenia okiem uzbrojonym, obok rozważań o teleskopie jako narzędziu zaspokajania ciekawości, uwagi dawnych autorów poświęcone temu urządzeniu splatały się z rozważaniami dotyczącymi tematyki eschatologicznej, obyczajowości oraz praktyki uprawiania astrologii.

Aby analizę źródel literackich i piśmienniczych ulokować we właściwym kontekście historycznym, przypomnijmy najważniejsze fakty z początkowego etapu naukowych zastosowań lunety². Zanim uczynimy to, zaznaczmy jeszcze, że w tekstach polskich nazywano ją „perspektywą”3. W łacińskim piśmiennictwie epoki współtworzonym przez dzieła polskich uczonych i artystów określano ją jako: organum, instrumentum, perspicillum [North 1997: 225], fistula dioptrica [Bucciantini, Camerota, Giudice 2015:10], telescopium.

$2 \mathrm{Z}$ bogatej literatury na ten temat zob. szczegółowe studia zawarte w: Helden, Dupré, Gent, Zuidervaart 2010.

3 „Wyraz [perspektywa] jest poświadczony od XVI w. [...], jednak wcześniej nie miał znaczenia astronomicznego" - podaje Waniakowa [2003: 118; zob też: 113, $126,128,129,135]$. 


\section{Teleskop w dziejach rewolucji naukowej}

„Ze wszystkich instrumentów astronomicznych żaden nie wywolał tak dramatycznego, natychmiastowego przewrotu w astronomii jak teleskop" [North 1997: 222]. Wynalazek ten, początkowo uznawany za ciekawostkę, rzecz z gatunku kuriozów, dzięki zastosowaniu go przez Galileusza do obserwacji nieba i publikacji jej wyników w Sidereus nuncius (1610), szybko zyskał rangę przyrządu o wyjątkowym znaczeniu naukowym [Fantoli 2002:97]. Powiadamiając o efektach swych badań, Galileusz podkreślat, że nie mają one precedensu w dotychczasowych dziejach nauki:

Zaiste wielkie są rzeczy, które w tym krótkim traktacie przedstawiam wszystkim badaczom natury do obserwacji i rozważań. Wielkie, rzekłbym, zarówno ze względu na doskonałość samego przedmiotu, jak i niespotykaną od wieków nowość, wreszcie ze względu na instrument, dzięki któremu zostały one ujawnione naszym zmysłom. Jest na pewno rzeczą wielką dodanie do licznego grona gwiazd stałych, które aż po dziś dzień można dostrzec nieuzbrojonym okiem, oraz ujawnienie wzrokowi niezliczonej liczby innych gwiazd, które nigdy dotychczas nie były widziane, w liczbie dziesięciokrotnie przewyższającej gwiazdy stare oraz znane. [Galilei 2010: 33]

Oglądanie Księżyca za pomocą teleskopu jest nie tylko źródłem estetycznej satysfakcji, lecz pozwala dostrzec, że Srebrny Glob, podobnie jak powierzchnię Ziemi, pokrywają szorstkości, nierówności, zagłębienia i krzywizny. Galileusz informował dalej, że nowe obserwacje wymagają korekty wcześniejszych poglądów na temat natury gwiazd mgiełkowych. Nade wszystko jednak obwieszczał o dostrzeżeniu „czterech gwiazd błądzących” - satelitów Jowisza, których dotąd nie znał ani nie widział żaden badacz nieba. „Wszystko to odkryłem i zaobserwowałem kilka dni temu za pomocą wynalezionej przeze mnie lunety, doznając z łaski Bożej olśnienia" [Galilei 2010: 34] - pisał uczony.

Wiadomości o niebie widzianym przez lunetę rozprzestrzenity się błyskawicznie. 500 egzemplarzy Sidereus nuncius zostało sprze- 
danych w ciągu tygodnia, a z całej Europy nadchodzily zamówienia na kolejne kopie. Publikacja tego dzieła wywarła „piorunujące wrażenie" [Wróblewski 1980: 475], a teleskop stał się narzędziem nieodzownym dla wszystkich uczonych aspirujących do udziału w dyskusji kosmologicznej [Bennett 2007: 129]. Recepcja pracy Galileusza komunikującej o efektach obserwacji nocnego nieba przez lunetę miała również polskie akcenty. Już w roku jej ogłoszenia zapoznał się z nią jeden z uczniów wielkiego astronoma - Krzysztof Zbaraski - który po lekturze „unosił się radością, że ich epoka przewyższyła starożytność, a Galileusz zapewnił już sobie nieśmiertelną sławę" [Targosz 2003: 54]. W tym samym roku Sidereus nuncius znalazł się w posiadaniu krakowskiego uczonego Jana Brożka - postaci, o której jeszcze będzie tu mowa [Targosz 2003: 66].

Teleskopowe obserwacje cial niebieskich szybko przyniosły kolejny, budzący zdumienie rezultat, jakim było odkrycie plam słonecznych. Początkowy etap poświęconej im dyskusji został zdominowany przez dwóch uczonych, którzy przedstawili jego różne wykładnie. Niemiecki jezuita Christoph Scheiner wyraził swą opinię w Trzech listach o plamach stonecznych (1612) i w rozprawie Accuratior disquisitio (1612), natomiast Galileusz zaprezentował swe stanowisko w listach naukowych znanych pod tytulem Relacja $i$ dowodzenia dotyczace plam słonecznych i ich charakterystyk (1613). Symptomatyczne, że niemiecki uczony, donosząc w pierwszym $\mathrm{z}$ wymienionych pism o plamach zauważonych na tle dysku słonecznego, zaznaczał, iż:

[... ] rzecz przekraczała nasze wyobrażenie, [dlatego] mieliśmy pewne wątpliwości co do realności zjawiska z powodu jakiejś nieznanej nam wady naszego wzroku czy też może teleskopu albo z powodu czegoś, co mogło zachodzić w atmosferze. [za: Sierotowicz 2013: 260]

Rozpatrując, czy „może teleskop wprowadza nas w błąd” [za: Sierotowicz 2013:261], relacjonował, że:

Aby wyjaśnić tę kwestię, użyliśmy ośmiu teleskopów o różnym powiększeniu i każdy z nich, zależnie od powiększenia, 
pokazał te same plamy na Słońcu. Jeśli jakiś teleskop ujawniał coś nowego albo jakieś zmiany, to samo pokazywały inne teleskopy. [za: Sierotowicz 2013: 261]

Obiekcje dotyczące tego, czy plamy słoneczne są „igraszką teleskopu czy jego soczewek" [za: Sierotowicz 2013: 365] oraz czy ich obraz mogą wywoływać „figle oczu” [za: Sierotowicz 2013: 372] co trzeba brać pod uwagę ze względu na nie w pełni rozpoznane mechanizmy fizjologii widzenia - rozważone zostały i ostatecznie oddalone również w drugim ze wskazanych dzieł niemieckiego astronoma.

W toku sporu dotyczącego plam słonecznych, obaj protagoniści, Scheiner i Galileusz, nie kwestionowali realności zaobserwowanego zjawiska. Nie byli jednak zgodni co do tego, jak należy je wyjaśnić. „Zawsze wydawało mi się niestosowne i w istocie rzeczy nieprawdopodobne, aby na powierzchni najjaśniejszego ciała, jakim jest Słońce, znajdowały się ciemne plamy [...]” oświadczał pierwszy z wymienionych uczonych [za: Sierotowicz 2013: 262]. W jego opinii „plamy te nie są prawdziwymi plamami, lecz raczej ciałami częściowo zaćmiewającymi część powierzchni Słońca" [za: Sierotowicz 2013: 262], dlatego opisywał je jako krążące wokół niego i rzucające na nie swe cienie „gwiazdy błądzące”, niedostrzegalne gołym okiem. Replikując na tę wykładnię, Galileusz dowodził, że plamy nie są ani gwiazdami, ani planetami obiegającymi Słońce, lecz znajdują się na jego powierzchni, a ich przemieszczanie się jest efektem ruchu obrotowego Słońca wokół własnej osi. Wytłumaczenie to oznaczało odrzucenie tradycyjnej, niedającej się już utrzymać, idei doskonałości Słońca. Zgodnie ze stanem faktycznym Słońce powinno być określane „jako pokryte plamami i ze skazami” [za: Sierotowicz 2013: 281], jako podlegające drobnym zmianom, które jednak nie świadczą o jego ułomności, lecz - podobnie jak zmiany dokonujące się na Ziemi - są jego „największą ozdobą” [za: Sierotowicz 2013: 460] ${ }^{4}$. usza oraz ujmowane pod kątem literackich, dialektycznych i retorycznych form, w jakich została zaprezentowana w pismach włoskiego astronoma, stanowi przedmiot odnotowanej wyżej wszechstronnej monografii Sierotowicza [2013]. 
Do rezultatów teleskopowych badań nieba, oprócz wymienionych wyżej, należało między innymi odkrycie faz Wenus i pierścieni Saturna [Roskal 2008: 407-422]. Nowe metody obserwacji umożliwiły powstanie nowożytnej selenografii, która w XVII wieku mogła poszczycić się takimi osiągnięciami, jak rozwój coraz bardziej precyzyjnej kartografii Srebrnego Globu czy wykrycie libracji Księżyca i jej wyjaśnienie [Włodarczyk 2005; Włodarczyk 2012: 211-266]. Luneta umożliwiła dokładniejsze niż dotychczas obserwacje komet. Począwszy od ich pierwszych badań prowadzonych za pomocą tego instrumentu, jasne stało się, iż nie jest wiarygodna arystotelesowska teoria komet, uznająca je nie za ciała niebieskie, lecz za wyziewy Ziemi i zaliczająca komety do zjawisk zachodzących w obszarze sublunarnym. Nowe dane dotyczące przemieszczania się komet $\mathrm{w}$ przestrzeni niebios wzmacniały argumentację przeciwników kosmologii arystotelesowskiej, którzy odrzucali charakterystyczną dla niej koncepcję stałych, krystalicznych sfer niebieskich.

Frontalna krytyka kosmologii arystotelesowskiej (dotycząca również innego z jej pryncypiów: tezy o niezmienności niebios) zyskiwała dzięki obserwacjom teleskopowym mocne podstawy. Gdyby Arystoteles dysponował wiedzą posiadaną współcześnie, to w kwestiach dotyczących astronomii „bez żadnej wątpliwości zmieniłby swe zdanie" [Galilei 1962: 58] - stwierdzał Galileusz w Dialogu o dwóch najważniejszych układach świata: Ptolemeuszowym $i$ Kopernikowym (1632).

[...] Niebo dzięki teleskopowi znalazło się od nas 30 czy 40 razy bliżej aniżeli było ono dla Arystotelesa - pisał dalej Galileusz - tak że możemy na nim obecnie dostrzec setki rzeczy, których on nie mógł zobaczyć, a między innymi owe plamy na Słońcu, które bezwarunkowo były dlań niedostępne. [Galilei 1962: 52]

Kontrowersje narastające wokół arystotelizmu zapowiadały odwrót od niego. Dokonywał się on jednak powoli, gdyż wiedza sygnowana autorytetem Mistrza dalej była użyteczna w wyjaśnianiu świata i w dużej mierze dawała się uzgodnić ze zdroworozsąd- 
kowym obrazem rzeczywistości. Była też powiązana z kulturowym i instytucjonalnym zapleczem funkcjonowania nauki, zwłaszcza w jej szkolnym czy popularyzatorskim wydaniu.

Dezaktualizacja kosmologii arystotelesowskiej dokonywała się jednak między innymi na skutek tego, że „teleskop dostarczał niezliczonych świadectw na rzecz kopernikanizmu" [Kuhn 2006: 252]. Teleskopowy ogląd gwiazd oraz Wenus pozwolił na rozwiązanie niektórych ściśle astronomicznych problemów, z jakimi mierzyli się zwolennicy teorii kopernikańskiej. Podobieństwa topografii Ziemi i wyglądu Księżyca podważały zasadność dawnego podziału na obszar ziemski i obszar niebieski, który po dostrzeżeniu plam słonecznych trudno było uważać za niezmienny, a zatem i za doskonały w tradycyjnym ujęciu. Wykrycie księżyców obiegających Jowisza stanowiło bodziec dla wyobraźni, gdyż obserwacje tej planety i jej satelitów mogły budzić nadzieje na odkrycie nieznanego wcześniej świata, odwzorowującego w mikroskali układ ciał niebieskich przypominających system heliocentryczny. Zaciekawienie, jakie powszechnie budził teleskop, przyczyniło się do rozpowszechnienia zainteresowań astronomią w zakresie dotąd niespotykanym ${ }^{5}$. Doprowadziło do wykreowania mody na prowadzone przez amatorów obserwacje nieba, a wreszcie do powstania nowych, literackich form popularyzacji wiedzy naukowej [Kuhn 2006: 253-258]. Rozgłos, jaki w XVII wieku zyskała astronomia, stanowił owoc oddźwięku, jaki miały teleskopowe obserwacje Galileusza, zaś „astronomia, którą spopularyzowały, była kopernikańska” [Kuhn 2006: 258].

Teleskop należał do tych instrumentów naukowych, które inspirowały optymizm poznawczy nowej nauki i stymulowały

5 Teleskop wywołał żywe zainteresowanie elit spoza kręgu ekspertów w zakresie astronomii - w tym poetów i filozofów, a jego sława wykroczyła poza terytorium Europy. Dzięki podróżnikom, dyplomatom i jezuickim misjonarzom teleskop trafił do Azji Wschodniej i Azji Południowo-Wschodniej. Oprócz zastosowań naukowych wykorzystywano go w nawigacji, w celach militarnych i rozrywkowych, a teleskopy wykonane z cennych materiałów świetnie sprawdzały się w roli prezentów, użytecznych w kontaktach dyplomatycznych [Bucciantini, Camerota, Giudice 2015; Zoomers 2010: 301-320]. 
utopijne wizje jej rozwoju w przyszłości, najsugestywniej zarysowane przez Francisa Bacona w Nowej Atlantydzie (1627). Czytamy tu, że „urządzenia, dzięki którym przedmioty mocno oddalone, np. znajdujące się na niebie albo w innych odległych miejscach, stają się dla oczu widzialne" [Bacon 1995: 79], należą do sprzętów wykorzystywanych przez uczonych z Domu Salomona, a prowadzących swe prace $\mathrm{z}$ intencją poznawania natury i poszerzania „granic władztwa ludzkiego nad nią” [Bacon 1995: 70]. Nawet o wiele ostrożniejsze prognozy dotyczące przyszłości nauki wskazywały na to, że badacze przyrody wyposażeni w teleskop (jak też w mikroskop) - doskonaląc te instrumenty i stosując nowoczesne metody wyjaśniania naukowego - ukażą wkrótce bogatszy o kolejne szczegóły obraz natury. Ten wyłaniający się stopniowo obraz rozsadzał ramy pojęciowe dawnych systemów filozoficznych oraz wywoływał pytanie o to, jak naprawdę przedstawiają się badane przez naukę zjawiska przyrodnicze. Nowe odkrycia pozostawiały wątpliwość co do tego, „co istnieje, a co nie istnieje, skoro jutro ujawnić mogło zgoła niewyobrażalne, bardzo małe bądź bardzo odległe obiekty [... ]" [Shapin 200o: 23-24].

\section{Scientia curiosa: luneta w barokowym teatrze zwierciadel}

Pora sięgnąć do dzieł autorów polskich. Dotyczą one rozległego repertuaru tematów, w których opracowaniu pojawia się luneta oraz odwołania do teleskopowej eksploracji nieba. Rozpocznijmy od kompendiów wiedzy, utworów należących do zasobów staropolskich tekstów paraliterackich [Dacka-Górzyńska, Partyka 2009].

W tych arcyciekawych źródłach sprzed kilku stuleci, rzucających wiele światła na horyzonty kultury i wyobraźni naukowej społeczeństwa Rzeczypospolitej, ważne miejsce zajmują publikacje, w których tematyka naukowa prezentowana była w popularnej w barokowej Europie konwencji scientia curiosa. Jej znak rozpoznawczy stanowiła dbałość o atrakcyjną formę przekazu. Przykuwając uwagę zaskakującymi konceptami, budząc zainteresowanie materią naukową (przedstawianą w sposób akcentujący niezwykłość natury - skarbca rzeczy ciekawych, unikatowych), 
twórcy spod znaku scientia curiosa zaspokajali estetyczne i poznawcze gusta czytelników. W ich pracach pojawiały się odniesienia do osiągnięć rewolucji naukowej. Zasadniczo jednak przedstawiali oni dorobek nauki odpowiadający jej przednowożytnym kanonom, osadzony w ramach tradycyjnego, religijnego obrazu świata. Wiodącą rolę w tej odmianie uprzystępniania wiedzy odgrywali jezuici ${ }^{6}$. Oddajmy głos dwóm z nich, koncentrując się na tym, co powiedzieli o lunecie.

Wojciech Tylkowski, największa sława naszej scientia curiosa, wspominał o niej w Uczonych rozmowach wszystkę $w$ sobie prawie zawierających filozofija (1692), swej głównej polskojęzycznej książce popularyzującej zagadnienia naukowe. Objaśniając budowę nieba „na którym są gwiazdy, a niżej nich planety” [Tylkowski 1692: 19], przybliżał obraz ciał niebieskich zgodny z tym, „jako się to przez perspektywy gwiazdarskie pokazuje” [Tylkowski 1692: 21]. Odpowiadając na pytanie "Jako wiele gwiazd?", wyjaśniał:

Im lepsze oko albo perspektywa, tym ich więcej kto obac $[\mathrm{z}] \mathrm{y}$, a na jednej niebo stronie, gdzie się bieli jest niepojęta ich liczba drobniusieńkich, których oko bez perspektywy nie dojrzy, tylo białość jakąś, i tak astrologowie coraz większą ich liczbę kładą. [Tylkowski 1692: 26]

Oznajmiając to, nie obwieszczał kosmicznych nowości. Dyskretnie jednak zaznaczał, że dzięki zastosowaniu lunety wiedza astronomiczna rozwija się, proces jej doskonalenia trwa i pozwala na uzupełnianie dawnych katalogów gwiazd.

Jak zajmująco przedstawić działanie lunety? Autor uznał, że właściwe będzie powiadomienie o tym w rozdziale książki poświęconym zmysłowi wzroku. Referował tu budowę oka, wady wzroku i sposoby ich korygowania za pomocą okularów, przybliżał zjawiska iluzji optycznej. W zestawie tematów dotyczących percepcji wzrokowej nie zabrakło odpowiedzi na intrygujące pytania:

6 Szerzej o scientia curiosa: Bargieł 1986; Bieńkowski 1987: 5-34; Bieńkowski, Dobrzycki 1998: 81-92; Lisiak 2005: 169-209. 
„Czy mógłby we dnie widzieć gwiazdy, gdyby w głęboką studnią się spuścił?” [Tylkowski 1692: 200], „Jak daleko może człowiek zajźrzeć?" [Tylkowski 1692: 199]. Percepcja wzrokowa, jej osobliwości i graniczne możliwości widzenia, powiązane ściśle z obserwacjami nieba - oto konteksty, w których pisarz postawił temat lunety. A uczynił to krótko, opisując konstrukcję teleskopu soczewkowego (refraktora) i wyjaśniając, dlaczego „przez perspektywę lepiej widać":

Dwie szkła ma perspektywa, jedno w końcu, a to puklaste, to zbiera w gromadę promienie, a im więcej promieni w oko wnijdzie od tejże rzeczy, tym jaśniej rzecz onę widziemy. Drugie szkło, które blisko oka, bywa wklęsłe, a to rozprzestrzenia promienie, aby na retynie większy obraz wyrazili, i dlatego przez perspektywę nie tylko jaśniej, ale i większą rzecz wiedziemy. [Tylkowski 1692: 205]

Twórca kolejnego kompendium odpowiadającego dyrektywom scientia curiosa umiejętnie czerpał z dorobku nauki czasów baroku, czyniąc to dla ukontentowania aspiracji poznawczych czytelnika, jak i po to, aby uczynić zadość jego zamiłowaniu do efektów specjalnych. Był nim Wojciech Bystrzonowski, autor Informacyji matematycznej rozumnie ciekawego Polaka (1743, druga, poszerzona edycja: 1749). Fascynował go potencjał iluzji tkwiący w zwierciadłach, których pomysłowe wykorzystanie dawało możliwość multiplikowania rzeczy widzialnych. Dlatego, unikając „przytrudnych szpekulacyji” [Bystrzonowski 1743, k. nlb.], podawał przepisy na sporządzenie „katoptrycznej skrzyneczki konstrukcyji do reprezentowania na podziw widowisk"[Bystrzonowski 1743, k. nlb.] oraz „sposób, aby w zwierciadle osoba przed zwierciadłem stojąca siebie widzieć nie mogła, lecz na przykład obraz świętego lub koczkodana jakiego" [Bystrzonowski 1743, k. nlb.]. Brylując konstrukcyjnymi pomysłami tego rodzaju - jak przyznaje, zapożyczonymi od poprzedników, w tym od Athanasiusa Kirchera, autora sławnej Ars magna lucis et umbrae (1645) - Bystrzonowski, gdy rozprawia dalej „o szkłach różnej figury i ich używaniu” [Bystrzonowski 1743, k. nlb.], robi to w sposób charakterystyczny dla jezuickiego obrazu 
świata. Nie wprowadza epistemologicznego rozgraniczenia religii od przyrodoznawstwa, za to kładzie nacisk na ich wzajemne przenikanie [Zieliński 2010: 153]:

Zaiste, przedziwne dzieło i cud natury, a raczej Autora Natury, Boga, lubo z swojej u ludzi estymacyji w podłych wydaje się szkiełkach. Z których jedne i najdalsze obiekta o milę i drugą, nawet same luminarze niebieskie, tuż przed oko stawiają. Drugie, najdrobniejsze atomiki, gołemu niewidome oku, odkrywają $[\ldots]$. [Bystrzonowski 1743, k. nlb.]

Charakterystyka „instrumentów dyjoptrycznych” [Bystrzonowski 1743 , k. nlb.] opisanych w Informacyji matematycznej jest więc rozpięta między wrażeniem wizualnej niezwykłości a celebracją potęgi majestatu boskiego odzwierciedlającego się w naturze. „Telescopia albo perspektywy” [Bystrzonowski 1743, k. nlb.] zostały tu wymienione obok mikroskopu, peryskopu i innych urządzeń, a ich opis brzmi następująco:

Astronomiczne bowiem perspektywy, służące do obserwacyji gwiazd i planet, obadwa szkła, tak okularne, jako i objektiwum, mają wypuklaste, dla większej aukcyji luminarzów, tak od oka odległych. Drugie perspektywy są o trzech lub czterech i piąciu szkiełkach, a czasem i więcej. Ale im więcej szkiełek, tym ciemniej rzecz reprezentują. [Bystrzonowski 1743, k. nlb.]

Skupiając się na generaliach, zaznaczmy, że obaj przytoczeni przed chwilą pisarze przedstawili krótko teleskop soczewkowy (refraktor). Pierwszy z nich odwołał się do wynalazku Galileusza, drugi - do instrumentu Keplera, wspominając też o stosowaniu przesłon, które ograniczały światło wpadające do urządzenia. Trudno orzec, dlaczego polscy autorzy nie uszczegółowili swego opisu, nadmieniając choćby o praktyce stosowania teleskopu jako urządzenia projekcyjnego, służącego do rzutowania obrazu ciał niebieskich na ekran, czy o montowaniu w teleskopie mikrometru okularowego. Żaden z cytowanych encyklopedystów nie wspominał o teleskopie zwierciadlanym (reflektorze), o którym wieści, 
wkrótce po jego skonstruowaniu, docierały do Polski. Na tle tych niedostatków, wynikających, być może, ze świadomej selekcji materiału naukowego, ograniczenia go do rzeczy najważniejszych, warto odnotować, iż Bystrzonowski w Informacyji matematycznej zwięźle naświetlił kwestię „sposobu widzenia przez perspektywy” [Bystrzonowski 1743, k. nlb.]. Podkreślit, że nie u wszystkich posługujących się tym instrumentem przebiega ono identycznie, gdyż „samego oka ludzkiego niejednaka konstrukcyja” [Bystrzonowski 1743 , k. nlb.].

\section{Obserwacje teleskopowe w kręgu dyskusji o systemie świata} i wielości światów

$\mathrm{Z}$ barokowego ogrodu nauk, widzianego oczyma pisarzy scientia curiosa, przenieśmy się w inne obszary ówczesnej kultury umysłowej. Uwagi poświęcone teleskopowi obecne były w wywodach mających za tło dyskusje naukowe, które toczyły się w tej epoce. Przyciągały uwagę tak ludzi pióra, jak uczonych.

Zważywszy na to, że prestiżu kosmologii arystotelesowskiej nie można było podważyć $\mathrm{z}$ dnia na dzień, zrozumiałe jest, że wiedza o zawdzięczanych teleskopowi odkryciach nie zawsze była impulsem dla afirmowania obrazu świata proponowanego przez nową naukę. Dotyczy to prac belgijskiego jezuity Karola Malaperta - astronoma i matematyka (a równocześnie literata poety i dramaturga), który jako pierwszy w Polsce zastosował lunetę do obserwacji nieba. Obserwacje te (skoncentrowane przede wszystkim na plamach słonecznych) prowadził w kaliskim kolegium jezuitów w latach 1613-1618, a jednym z uwypuklanych przez historyków nauki efektów jego działalności było opracowanie prototypu paralaktycznego montażu lunety [Przypkowski 1960: 164-170, 175-186]. W jego przypadku nowatorskie podejście do techniki obserwacji teleskopowych nie szło w parze ze śmiałością $\mathrm{w}$ formułowaniu wniosków wyprowadzanych z nowoczesnych studiów nieba. Malapert, referując je w dysertacji Austriaca Sidera heliocyclia astronomicis hypotesibus illigata (1633), utrzymywał bowiem, iż plamy nie są umiejscowione na tarczy słonecznej, lecz są cieniami, rzucanymi na Słońce przez odrębne planety oraz 
niewielkie gwiazdy, które „obiegają Słońce własnymi ruchami”. W geście rewerencji wobec austriackich Habsburgów nazwał je „Gwiazdami Austriackimi” [Malapert 1633: 1] 7 .

Malapert prowadził swe badania, pozostając w kontakcie naukowym ze wspomnianym już Scheinerem, który pełnił też rolę inspiratora prac, jakie pod okiem nauczycieli z jezuickiego kolegium we Fryburgu w Bryzgowii podjął Jan Mikołaj Smogulecki. Ich pokłosiem była dysputa Sol illustratus ac propugnatus (1626), będąca „poważnym studium obserwacyjnym plam słonecznych" [Przypkowski 1975: 238], a równocześnie publikacją, która w toczącym się sporze o heliocentryzm opowiadała się przeciw tej teorii [Bieńkowska 1971: 115-116]. Co symptomatyczne, na stronicach tej rozprawy autor nadmieniał, że wśród uczestników dyskusji astronomicznych są tacy, którzy obstają przy zrozumiałych wcześniej, lecz, jak pisał, obecnie niedających się utrzymać obiekcjach i „jeszcze teraz odważają się twierdzić, że te gwiazdy czy też plamy widziane na Słońcu występują w powietrzu, na szkle lub w oku [obserwatora] lub w miejscu [innym] niż w atmosferze Słońca $[\ldots]^{8 ”}[$ Smogulecki 1626: 38$]$.

Odważne konkluzje naukowe wieńczyła praca profesora Akademii Krakowskiej Wojciecha Rajmunda Strażyca Quaestio astronomica (1640). Jej podstawą były badania plam słonecznych prowadzone za pomocą lunety, którym przyznano „samoistną wartość dla historii astronomii planetarnej pierwszych dziesięcioleci ery teleskopowej" [Bieńkowski, Dobrzycki 1998: 52]. W publikacji tej wyjaśnienie plam jako zjawiska zachodzącego na powierzchni Słońca, wraz z odwołaniami do innych odkryć dokonanych przy użyciu lunety, budowało argumentację przemawiającą na niekorzyść nauki starożytnej, zwłaszcza kosmologii arystotelesowskiej. Pozwalało ono uznać prawomocność nowych metod naukowych i wiarygodność opisu świata bazującego na obserwacji. Nie bez powodu odnotowaną rozprawę uznano za ważne potwierdzenie obecności „Galileuszowskiego lobby” na krakowskiej uczelni, podnosząc przy tym, iż źródła jej inspiracji, zaczerpnięte z kształtującej 
się nowoczesnej metodologii przyrodoznawczej, nie zostały przez autora ujawnione [Dobrzycki 1998: 73-80].

Nie zostały ogłoszone drukiem, nie podlegały też innej formie upublicznienia refleksje Jana Brożka, które za chwilę przytoczymy. Jego postać znana jest tak dziejom nauki (głównie astronomii i matematyki), jak historii literatury, a rękopiśmienna spuścizna, którą pozostawił, wyrasta na przecięciu nauki i sztuki słowa. W integrowaniu idei naukowych z subiektywną, literacką formą wyrazu pomocna była mu poetyka „mikroeseju” [Kołos 2015: 123], w której formułował przemyślenia na temat epistemologicznych i religijnych aspektów nowej nauki. Refleksje te spisywał w raptularzach oraz na marginesach książek z bogatego księgozbioru, który gromadził z wrażliwością bibliofila i uczonego. Wśród jego uwag zredagowanych w konwencji miniaturowego eseju pojawił się temat teleskopowych obserwacji nieba. Ów uczony i „pisarz-literat wychodzący poza właściwe granice fachowego piśmiennictwa naukowego" [Barycz 1954: 61], tak pisał w raptularzu wszytym do zakupionego w 1617 roku dzieła Kopernika Astronomia instaurata:

Oko skierowane bezpośrednio na gwiazdy widzi te, które obserwowali wszyscy starożytni. Z pomocą zaś lunety dostrzega o wiele więcej, i te, które poprzednio widziało mglisto, dostrzega jako jasne i świecące. Na większą odległość sięga więc wtedy siła widzenia i lepiej odróżnia przedmioty. Otóż doskonała luneta wykazuje, że gwiazdy, uważane dawniej za najodleglejsze, znajdują się wewnątrz wszechświata. Obserwacje te skłaniają mnie bardzo do przekonania, że gwiazdy stałe nie są równo odległe od naszego oka. Należy to rozumieć jak następuje: Arktur oddalony jest od nas na pewną określoną odległość, jedna z Plejad odległa jest na większą odległość tak, że jej oddalenie od nas przewyższa odległość Arktura. Przyjmuję z wielkim prawdopodobieństwem, że to samo należy sądzić o innych gwiazdach, których niezliczoną ilość dostrzegamy. Przekonywać bowiem o tym zdaje się tak wielkie skupisko gwiazd, jakie dostrzegamy za pomocą instrumentu skierowanego na drogę mleczną. A może za skupisko uważamy 
to, co nie jest skupiskiem: gwiazdy owe mogą bowiem być od siebie oddalone na wielką odległość, chociaż nam się zdają tak stłoczone i jak gdyby skupione w jeden organizm. [Brożek 1956: 158-159]

Jak w wielu naukowych i literackich utworach epoki, tak i w przytoczonych zapiskach wybrzmiewa refleksja o przekroczeniu horyzontu poznawczego nauki starożytnej. Wzmocniona dzięki lunecie „siła widzenia” na tyle znacząco poszerzyła zasoby danych obserwacyjnych, że zasadne stało się przypuszczenie, iż dotychczasowe szacunki dotyczące rozmiarów wszechświata wymagają gruntownych korekt. W latach, w których zredagowane zostały cytowane zapiski, problematyka badań nieba okiem uzbrojonym splatała się między innymi z rozważaniami dotyczącymi nieskończoności kosmosu. Choć oczywiste było, że teleskop poszerza obszar percepcji zmysłowej, to jednak:

[... ] nie zmienia zasadniczej struktury naszego oglądu świata. Czy to przy pomocy teleskopu, czy bez jego użycia, i tak nie można zobaczyć rzeczy znajdujących się w nieskończonej odległości. Świat optyczny jest skończony. [Koyré 1998: 93]

Oglądanie firmamentu przez teleskop nie pozwala więc na rozstrzygnięcie intrygującego Brożka problemu nieskończoności świata9. Skierowanie lunety na niebo skłania jednak do wniosku, że ogrom wszechświata może wymykać się naszym rachubom i dlatego prowadzi do sformułowania następującego przypuszczenia:

Tyle [jest] gwiazd i w takiej od siebie odległości, że ziemia w porównaniu z ich wielkością jest punktem, czyli czymś znikomym i niemal niepodzielnym. Nie wątpimy, że wszystko na ziemi istnieje dla człowieka, najdoskonalszego ze stworzeń. Ale żeby Słońce i taką liczbę gwiazd stworzono jedynie ze względu na mieszkańców ziemi, nie wydaje się nam pewne [...]. [Brożek 1956: 160] 
Kosmiczne dystanse unaoczniane przez teleskop każą ze sceptycyzmem odnieść się do antropocentryzmu jako zasady tłumaczącej teleologię wszechświata. Co za tym idzie, uprawomocniają przypuszczenie, że wszechświat, którego rubieże przesunęły się na ogromną, trudną do ustalenia odległość, jest, być może, zaludniony nie tylko przez człowieka, lecz też przez inne żywe istoty. Ich istnienie wydaje się wysoce prawdopodobne - głosi nasz autor, a jego argumentacja jest zbieżna z poglądem zwolenników idei wielu zamieszkałych światów. Bo przecież trudno obronić twierdzenie, że Bóg stworzył olbrzymi wszechświat, jedynie część jego przestrzeni przeznaczając do zasiedlenia przez żywe organizmy [Lovejoy 1999: 150-151].

Barokowa fantastyka orędowała za tym, iż poważnie trzeba liczyć się z tym, że nasza planeta nie jest jedynym obiektem w kosmosie, na którym rozwinęło się życie. Nowy sprzęt służący studiowaniu nieba sprzyjał tego rodzaju deliberacjom, a przekonuje o tym wypowiedź astronauty, bohatera międzyplanetarnej podróży, ukazanej przez Cyrana de Bergeraca w powieści Tamten świat (1657). Główny bohater utworu, jak każdy światowiec chcący rozprawiać o naukowych nowościach, dysponuje lunetą i dlatego obiecuje innej postaci z tejże powieści, panu de Montmagnie:

[...] jeśli będę miał kiedyś honor spotkać pana we Francji, pokażę panu przez najwyborniejszą lunetę, a posiadam taką, że pewne zaciemnienia, które stąd wydają się plamami, to kształtujące się światy. [Bergerac 1956: 63]

\section{Teleskop, mieszkańcy Księżyca i spór z arystotelizmem}

Teleskop wzmacniał nadzieje na to, że o zasiedleniu innych ciał niebieskich, zwłaszcza Księżyca, można będzie przekonać się naocznie. W związku z tym popuszczano wodze fantazji. Formułowano też bardziej lub mniej śmiałe hipotezy. W ostrożny, powściągliwy sposób stawiał je Jan Heweliusz, rozważając realność istnienia Selenitów, mieszkańców Srebrnego Globu, na kartach swej pierwszej, najsłynniejszej pracy Selenographia sive lunae descriptio (1647). Rozpatrzył ten temat przy okazji innych astronomicznych 
zagadnień, nie roztrząsając kwestii takich jak wygląd istot zaludniających Księżyc [Jasiński 2013: 61-67].

$\mathrm{Z}$ tego, że teleskop nie pozwala dostrzec na Srebrnym Globie istot żywych, nie powinniśmy wnosić, że ich na nim nie ma, wywodził gdański astronom, zaznaczając, że instrument ten nie mógłby dostarczyć wiarygodnych dowodów również na to, co dzieje się na naszej planecie, gdybyśmy mogli na jakiś czas przenieść się na Księżyc „i przy pomocy najlepszych teleskopów oglądać stamtąd Ziemię" [Heweliusz 1977: 184]. Używając tych narzędzi, nie zauważylibyśmy ani żadnych istotnych zmian zachodzących na jej powierzchni, „ani domów, ani wież, ani roślin, drzew lub zwierząt” [Heweliusz 1977: 184]. Wychodząc od naukowego zastosowania teleskopu, autor Selenografii przechodzi do ogólniejszych zagadnień poznania naukowego. Podkreśla, że nie tylko w astronomii, lecz i w innych dziedzinach wiedzy ludzie zostali postawieni przed koniecznością przyjęcia do wiadomości faktów, „których umysł nie przewidział”, takich jak te, iż „w Afryce i w Ameryce istnieje tyle zadziwiających rodzajów zwierząt, tak wiele rodzajów owoców i roślin $[\ldots]$, tak niezliczona ilość obcych nam ślimaków i muszli” [Heweliusz 1977: 185]. Wszystko to powinno usposabiać do poznawczej ostrożności, zwłaszcza wobec twierdzeń naukowych ufundowanych wyłącznie na rozumowaniu, pozbawionych podstaw obserwacyjnych. A te, w skali dotąd niedostępnej nauce, wzbogaciły się właśnie dzięki teleskopowi. Heweliusz przypominał o tym „środowisku perypatetyków”, uparcie trwającemu przy twierdzeniu o niezmienności niebios i kwestionującemu obraz uniwersum udostępniony „przy pomocy lunety”. Widziane przez nią Droga Mleczna, Wenus, Merkury, Księżyc i Słońce (pokryte pojawiającymi się i znikającymi plamami) wyglądają inaczej, niż wyobrażają to sobie perypatetycy. Dlatego z zaprzysięgłą konsekwencją odrzucają możliwość jej wykorzystania, aby dostarczony dzięki niej „naoczny dowód nie zmusił ich do zmiany fałszywej opinii” [Heweliusz 1977: 185].

Gdański astronom już we wstępie do swego znakomitego debiutanckiego dzieła podkreślał, że „bez posługiwania się teleskopem obserwacje niebieskie nie mogą być w ogóle przeprowadzane" [Heweliusz 1977: 178]. W selenograficznym opus magnum 
wyróżnił on kilka rodzajów przyrządów optycznych. Były to urządzenia należące do instrumentarium astronomicznego: „telioskop” (teleskop) oraz „helioskop” (uczony nazywał tak lunetę z ekranem służącym do projekcji obrazu Słońca). Były też takie, które nie miały zastosowania w studiowaniu nieba: mikroskop oraz „polemoskop” (peryskop) [Rybka 1987: 134]. Na rycinach, które zawiera Selenografia, widnieją precyzyjnie odwzorowane konstrukcje tak tradycyjnych, jak najnowszych instrumentów astronomicznych. Co najważniejsze: praca ta zawiera, sporządzone na podstawie obserwacji teleskopowych, mapy powierzchni Księżyca oraz atlas jego faz, dzięki czemu w prezentowanej deskrypcji Srebrnego Globu ryciny są równorzędną w stosunku do tekstu, o ile nie dominującą, częścią naukowego przekazu [Włodarczyk 2011: 215]. W historii nauki selenograficzne dzieło gdańskiego astronoma:

[...] jest uznawane za pierwszą książkę, która z sukcesem odpowiedziała na potrzebę stworzenia - za sprawą pojawienia się nowego instrumentu, teleskopu - obrazowego języka astronomii i która stała się wzorem, w jaki sposób astronomiczną informację należy wizualnie komunikować. [Włodarczyk 2011: 218]

Badania nieba Heweliusz prowadził niestrudzenie w kolejnych dekadach w swym unikatowym na skalę europejską obserwatorium. Było ono miejscem wizyt nie tylko uczonych, lecz i monarchów, arystokratów czy ludzi pióra, a gościom niewtajemniczonym $\mathrm{w}$ arkana profesjonalnych prac astronomicznych dawały emocjonującą sposobność oglądania firmamentu przez lunetę ${ }^{10}$. Rezultaty swych badań Heweliusz ogłaszał w licznych publikacjach, które - dzięki zamieszczonym w nich, perfekcyjnie wykonanym rycinom - pozwalają zobaczyć, jak wyglądał jego sprzęt obserwacyjny. Jego nieodzownym składnikiem były lunety, wyróżniające

Zagadnienia te, jak też problematykę zainteresowań astronomicznych ówczesnych elit władzy i kultury naświetla Targosz [1975: 290-300; 1991: 308-357; 1997: 392-460]. 
się nie tylko ogromnymi rozmiarami, lecz i misterną, efektowną ornamentyką ${ }^{11}$.

Wytworny estetyzm był też wyróżnikiem książek jego autorstwa. W niektórych z nich, w eksponowanych miejscach - takich, jak frontyspis i karta tytułowa (z sygnetem prywatnej drukarni astronoma czy emblematyczną winietą) - pojawiają się rysunki lunet. Ich znaczenie naukowe zostało w ten plastyczny sposób udobitnione tak w krótkich, jak w monumentalnych dziełach Heweliusza. Na frontyspisach, obok Selenografii, widzimy je w traktatach, takich jak Cometographia (1668), Prodromus astronomiae (1690), dostrzegamy je na winietach zdobiących inicjalne karty dedykacji widniejących w Machinae coelestis pars prior (1673) oraz w Machinae coelestis pars posterior (1679). Osobnego uwydatnienia wymaga fakt, że astronomiczne prace Heweliusza wywołały żywy oddźwięk literacki, stając się tematem laudacyjnej poezji okolicznościowej, której obfite zasoby powstały w jego rodzinnym mieście, Gdańsku ${ }^{12}$.

\section{Nowa nauka i świecka ciekawość}

Prywatna edukacja, jaką odbył u Heweliusza młody Stanisław Herakliusz Lubomirski [Targosz 1975: 69, przypis 103] - erudyta, oryginalny i wszechstronny pisarz, była zapewne znaczącym wydarzeniem w jego biografii intelektualnej. Zważywszy na to, że przyszły znakomity literat był miłośnikiem sztuki, współtwórcą programów użytkowych i ikonograficznych swych rezydencji, wolno przypuszczać, że mógł na nim wywrzeć wrażenie szczególny styl kultury naukowej gdańskiego astronoma, w której dbałość o techniczną doskonałość naukowego warsztatu konweniowała z wyrafinowanym gustem, z jakim był tworzony. A że kontakty intelektualne łączyły Lubomirskiego również z wybitnym francuskim astronomem Ismaëlem Boulliau [Targosz 1975: 68], jak też 
z zadomowionym w Rzeczypospolitej włoskim inżynierem i konstruktorem lunet Tytusem Liwiuszem Burattinim - cenionym przez zachodnioeuropejskich ekspertów biegłych w ich doskonaleniu, osiągającym też znaczące rezultaty na polu obserwacji astronomicznych [Targosz 1975: 300; zob. też: 290, 293-302] - nie jest zaskakujące, że w twórczości polskiego pisarza raz po raz pojawiają się wzmianki o lunetach czy też aluzje do odkryć, jakich dzięki nim dokonano. W jego utworach nie zawsze mowa o nich wprost, choć z kontekstu wypowiedzi jednoznacznie wynika, że pisarz opowiada właśnie o tym instrumencie. „Daleką ścieżkę do gwiazd skróciła ustawiczna wiedzenia chciwość, aby odległe stały się bliskiemi" [Lubomirski 1916: 129] - notował Lubomirski w dialogu politycznym De vanitate consiliorum (1700). O nowej jakości poznania, jaką umożliwił teleskop, pisał w eseistycznych Rozmowach Artaksesa i Ewandra (1683). Stwierdzał tu, iż „w Słońcu, które jest najznaczniejsze i najzacniejsze w swym pozorze, a przecię ludzie znaleźli jakieś zmazy i makuły i pokazali, że ich i na samym niebie domacać się i one wytropić umieli” [Lubomirski 2006: 118-119]. I znów: choć komentowane są tu rezultaty obserwacji, w toku których zastosowano lunetę, nie zostaje ona wymieniona. Pisarz daje jednak do zrozumienia, że jest to wyjątkowo wrażliwe narzędzie badania natury, którego używanie wymaga specjalnych, „myśliwskich” umiejętności. Luneta - choć prowadzi do rezultatów zdumiewających, bo podważających doskonałość Słońca - jest źródłem wiedzy pewnej, niepodważalnej. Podkreśla to odwołanie do konkretności, z jaką człowiek odczuwa wrażenia rejestrowane przez dotyk - plam ludzie potrafili wszak „domacać się” w najszlachetniejszym ciele niebieskim. Metaforyka sięgająca dotyku, dostarczającego doznań konstytuujących ludzkie doświadczanie cielesności, odwołuje się do zmysłu, który, w odróżnieniu od wzroku, nie podlega zwodzącej iluzji [Hanusiewicz 2004: 122-123]. Wrażenia dotykowe, odniesione do tego, co, objawiło się wyposażonym w lunetę astronomom, są sensualnym gwarantem wiarygodności poznawczej. Potwierdzają więc realność plam wykrytych na tarczy słonecznej. Dodajmy, że to, jak luneta zwiększyła możliwości percepcji wzrokowej, przykuwało uwagę literatów, zmierzających do obrazowego ujęcia skali poznawczego 
przełomu. John Milton w Raju utraconym (1667) pisał, że widoki niczym nieprzesłonięte i rozleglejsze od tych, które ukazało „szkło Galileusza” [Milton 1986: 122] dostępne są aniołowi mknącemu przez niebiosa - wynika z tego, że „toskański astronom” [Milton 1986: 16] osiągnął dzięki swemu instrumentowi apogeum tego, co uchwytne dla ludzkiego wzroku. Poznawczy zwrot z właściwym sobie humorem komentował Bernard Fontenelle w Rozmowach zmarłych (1683). Tu, w jednym z dialogów toczących się w zaświatach, Galileusz słyszy z ust swego interlokutora, Apicjusza:

Udoskonaliłeś więc zmysły i nauczyłeś innych udoskonalać je dalej. Byłbym cię więc prosił, abyś popracował także nad udoskonaleniem smaku i wymyślił jakiś przyrząd, który zwiększyłby przyjemność jedzenia. [Fontenelle 1961: 148]

Skoro zaś mowa o literackich kreacjach postaci Galileusza, zaznaczmy, że teksty artystyczne były środkiem upowszechniania wiadomości o jego odkryciach. Czytelnicy i ludzie pióra w Rzeczypospolitej mogli dowiedzieć się o nich między innymi $\mathrm{z}$ arcydzieła Giambattisty Marina Adon (1623), którego obszerne fragmenty zostały w czasach baroku przełożone na język polski. Zachowane przekazy rękopiśmienne tej translacji mają jednak luki i nie obejmują partii utworu, w których mowa o Galileuszu oraz o teleskopie [Marino, Anonim: 1993: 468].

Od aplauzu dla efektów, jakie przyniosło naukowe zastosowanie lunety, już tylko krok do szerzej zakrojonej refleksji na temat osiągnięć techniki i nowej nauki, której triumfy uwidoczniły się na polu astronomii. Wypowiedział ją sarmacki twórca Wespazjan Kochowski w często cytowanym wierszu Tablica $z$ napisem rymu słowiańskiego, wielkiemu cnota i nauka, Justowi Lipsjuszowi Beldze ze zbioru Niepróżnujące próżnowanie (1674). Wywodząc, że „próżne starych wieków dumy” - bo przerastają je osiągnięcia czasów nowszych: podróże transoceaniczne, wynalezienie druku i prochu strzelniczego - poeta pytał retorycznie:

Kto z starych widział w Słońcu skazy?

Liczbę gwiazd większą po dwa razy? 
Coraz leniwszy pojazd Feba,

Insze sekreta tajne nieba.

[Kochowski 1674: 326]

Wyliczając to, co dostrzeżono przez lunetę - o której od dawna było głośno, więc nie trzeba było mówić o niej explicite - poeta ogranicza się do generaliów. Mimo to przy wielekroć przytaczanym tekście warto zatrzymać się, by podkreślić, że na tle sarmackiego dystansu czy nawet niechęci wobec odczytań księgi natury proponowanych przez nową naukę [Hanusiewicz 1998: 46-64], utwór wyróżnia się zdecydowanie afirmatywnym stosunkiem wobec niej. Co więcej, obok odkrycia plam słonecznych i nowych gwiazd, atutem nowożytnej nauki jest też to, iż ukazuje „Coraz leniwszy pojazd Feba”. Te zagadkowe słowa barokowego twórcy jeden ze współczesnych badaczy uznał za „coś w rodzaju wyznania - osłoniętego nieśmiało poetycką metaforą - że akceptuje on kopernikańską teorię systemu słonecznego, co w środowisku, do którego należał, nie było pozbawione zasługi” [Backvis 1993: 279].

Przyjmując do wiadomości, iż obserwacje teleskopowe wymagają uzupełnienia dawnych katalogów gwiazd, barokowi autorzy wyrażali opinię, że choć niebo pokryte świetlistymi punktami widzimy lepiej niż kiedykolwiek w przeszłości, to w gruncie rzeczy ów przyrost wiedzy uświadamia, że niemożliwe jest, aby ostatecznie stała się ona definitywna i pełna. W tym tonie wypowiadał się znakomity dominikański kaznodzieja Fabian Birkowski w Na dzień Trzech królów kazaniu. O rozsądkach abo obwieszczeniach astrologów, zawartym w zbiorze Kazań na niedziele $i$ święta doroczne (1623-1628):

Astronomem był Abraham, rad często na gwiazdy patrzał i do nieba wzdychał, jako czynił ś. Ignacyjus, Societ[atis] Iesu fundator, którego one słowa są: „Jako mi śmierdzi ziemia, gdy na niebo wejźrzę". Dojźrzane gwiazdy są nam niewyliczone, bo jako Augustyn ś. mówi: „Im kto bystrzejszego wzroku, tym ich więcej na niebie upatrzy”. Nowa dyjoptra daleko ich więcej jeszcze ukazuje, których oko samo dojźrzeć nie może. Niektórzy wprawdzie z Ptolemeusza i z astrologów liczą ich tylo 1022, 
ale tylo znaczniejszych, świetniejszych ta liczba jest; bo kto owe drobne wyliczy, Bóg tylo sam, który zna czeladkę swoję. [Birkowski 2012: 68]

W związku z ujęciem omawianej tematyki w kontekście religijnym, zaznaczmy, że pojawiały się w nim czasem charakterystyczne obiekcje. Luneta trafiała za mury klasztorów i uznano ją za przyrząd, którego niewłaściwe używanie może utrudniać pełne odseparowanie klauzury od świata zewnętrznego. Stąd rzymska Kongregacja do Spraw Zakonów w 1627 roku pod sankcją „„surowej kary” zakazywała „posługiwania się «długim okularem», czyli lunetą, gdyby miała ona służyć zaspokajaniu ziemskiej ciekawości, a nie badaniu nieba" [Rosa 2001: 246]. Okazuje się, że nawet w sytuacji wykorzystania lunety zgodnie z jej przeznaczeniem naukowym, posługiwanie się nią może wywoływać zastrzeżenia. Zapewne chciał je zasugerować wspomniany wcześniej Kochowski, odnosząc się do dokonanych za pomocą lunety obserwacji Słońca w jednym z utworów z poematu maryjnego Ogród panieński (1681). W tym pobożnym wirydarzu chwałę Najświętszej Panny głosi między innymi wiersz Sine macula:

W Słońcu skazy dwornością dociekł gwiazdarz biegłą, Ja twierdzę Pannę skazie żadnej niepodległą.

[Kochowski 1681: 47]

Koncept służący uwzniośleniu Matki Boskiej jest wyrazisty. Jej czystość kontrastuje ze skazami szpecącymi Słońce, które badacz nieba wykrył „dwornością [... ] biegłą”. Mając na względzie właściwe dla dawnej polszczyzny znaczenia słów, którymi posłużył się poeta, zauważamy, że wyakcentował on nie tylko rolę „biegłości”, a więc takich cech pracy „gwiazdarza”, jak „doskonała znajomość rzeczy”, „umiejętność”, „doświadczenie” czy „wiedza” [Słownik polszczyzny XVI wieku 1967: 128]. Barokowy autor uznał, że prawdy o plamach słonecznych „gwiazdarz” dowiódl „dwornością”, a więc postawą, którą cechuje „zbytnia, próżna ciekawość, dociekliwość”, postawą określaną przez „appetitus rerum novarum, curiositas”, a także przejawiającą się zainteresowaniem „rzeczami 
niezwiązanymi z religią”, „świeckimi” [Słownik polszczyzny XVI wieku 1972: 255]. „Dworność” poczynań „gwiazdarza” przeniknięta jest więc poznawczą nadmiarowością i lokuje się w obszarze różnym od domeny spraw boskich. Czy to, że posuwa się o krok za daleko jest efektem uzbrojenia go w lunetę? Barokowy wiersz może skłaniać do wysnucia takiego wniosku. Wobec tego mielibyśmy do czynienia z sytuacją, w której teksty jednego autora komentującego naukowe zastosowania teleskopu, mówią o jego użyciu bardzo różnie: raz z entuzjazmem, a raz z nutą sceptycyzmu.

Obraz nieba uzyskany „dwornością [...] biegłą” przypomina, że profesji astronomów właściwe jest mierzenie się ze sprawami odległymi od oswojonych, bliskich potocznemu doświadczeniu rzeczy ziemskich. Tak widziała fach astronomów Elżbieta Drużbacka - „zmysłowa i elokwentna prowincjuszka na staropolskim Parnasie" [Stasiewicz 2001]. Sięgające nieba aspiracje poznawcze astronomów poetka skontrapunktowała z deklaracją poznawczej pokory i autorskiej skromności. Zapewniała o nich w Opisaniu czterech części roku, a więc w utworze, który opowiadał o tym, co znane i bliskie. Dotyczył tematu o dużej nośności, współtworzącego ciągłość dawnej kultury, a pisarzom podejmującym ten temat zapewne dawał poczucie zakotwiczenia w niej. Wspomniany tekst, zamieszczony w Zbiorze rytmów duchownych, panegirycznych, moralnych $i$ światowych (1752), zawiera następujące wyznanie poetki:

Ja w równość z żadnym uczonym nie wchodzę,

Bojąc się porwać na słońce z motyką,

Po niskiej ziemi, nie po niebie chodzę,

Ni się pochwalić, z tą mogę praktyką,

Żebym wiedziała, czego dowcip chciwy

$\mathrm{Z}$ astrologicznej dojrzy perspektywy?

Dosyć tu będzie na mój rozum podły,

Nie potrafiwszy gwiazd na niebie zliczyć,

Przynajmniej w lesie dęby, sosny, jodly

Rachować w tej się arytmetyce ćwiczyć.

A co na ziemi Bóg dał widzieć oku,

Chwalić Go zacznę w czterech częściach roku.

[Drużbacka 2002: 9-10] 
Motyw lunety jako instrumentu pomocnego w zaspokajaniu ciekawości - potrzeby oglądania, którą trudno utrzymać w ryzach - bywał składnikiem barokowych opisów miłości. Zgodnie z toposem quinque lineae amoris uprzywilejowaną rolę odgrywały w nich doznania wzrokowe, $z$ tego bowiem sensualnego obszaru płynąć miały bodźce wzniecające namiętność [Curtius 1997: 540-542; Hanusiewicz 2004: 32-64]. Gdy więc u schyłku XVII wieku Adam Korczyński w spisanej mową wiązaną noweli Wizerunk złocistej przyjaźnią zdrady mówił o młodym Polaku zachwyconym urodą pięknej Włoszki, zanotował, iż widok tej damy, gdy „w przezroczystem rąbku przeciw okna stała”, był porywający, gdyż jej „alabastrowe ciało jako w perspektywie / z najskrytszemi członkami mógł widzieć prawdziwie" [Korczyński 2000: 40]. Splatające się z sobą ciekawość i przyjemność oglądania mogą okazać się zgubne, zwłaszcza, gdy wizualne olśnienia zostaną zintensyfikowane przez użycie lunety. Uwydatniła to przywołana już Drużbacka w poetyckiej redakcji mitologicznego przekazu zawartej w wierszu Opisanie oczu ciekawych Akteona:

Często ciekawe oko szkodę czyni w duszy, Często w niewolne jarzmo wolnego zaprzęga.

Oko nasz nieprzyjaciel, mózg i ciało suszy,

Zdrów dopiero, wnet z niego żebrak niedołęga.

Choruje, napiera się, a nie wie, że w trunku

Zamiast lekarstwa bierze złą śmierć w basarunku.

Teć to są perspektywy misternej roboty.

I choć z daleka patrząc, nie nasyca wzroku,

Pędzi ciekawość szybko, dodaje ochoty,

Pozwala bezpieczeństwa przyspieszając kroku.

Zaciekły oślep bieżąc, często w przepaść mierzy,

Oczy traci, gdy głowę o skałę uderzy.

[Drużbacka 2002: 62]

\section{Luneta i widzenie rzeczy ostatecznych}

Kolejne zastosowanie motywu lunety kieruje naszą uwagę ku barokowej emblematyce religijnej. Odwołując się do prymarnej 
funkcji teleskopu - przybliżania obiektów odległych - autorzy emblematów czynią z niego metaforę „długiego widzenia”, które identyfikują z roztropnym przewidywaniem rzeczy ostateczny $\mathrm{ch}^{13}$. W tym ujęciu, zawdzięczającym ideowe korzenie aretologii chrześcijańskiej, widzenie przez teleskop jest metaforą przenikliwości poznawczej, pozwalającej przybliżyć to, co odległe w czasie eschatologiczne przeznaczenie człowieka. Wśród utworów realizujących ten motyw oryginalnością konkretyzacji artystycznej wyróżnia się Zbigniewa Morsztyna Emblema 96 ze zbioru Emblemata. Zapisane tu roztrząsania o nieubłaganym przemijaniu rzeczy doczesnych wieńczy apel, aby „zaślepiony” człowiek sięgnął po „perspektywę”, pozwalającą patrzeć „na świetne niebieskie tryjony” i przekonać się, jak wielkich strat doznaje ten, kto „nie z niebem, lecz z ziemią się braci” [Morsztyn 2001: 199]. Co znamienne, ukazując lunetę jako instrument unaoczniania rzeczy ostatecznych, emblematyczna poezja sięga też po koncept spoglądania przez lunetę odwróconą: obserwator patrzy $\mathrm{w}$ dal przez obiektyw zamiast przez okular. „Rzecz perspektywa lepiej pokazuje”, dzięki niej „wyraźnie oko zajźrzy wszędzie”- pisał Michał Mieleszko w Nabożnych westchnieniach (1657) - jednak brak umiejętności w posługiwaniu się nią sprawia, iż dusza - błędnie - jako odległą w czasie postrzega realność śmierci, sądu bożego, nieba lub piekła. Konieczne jest więc odwrócenie teleskopu. Jak dowiaduje się pouczona w tym względzie dusza, sprawi to, że „z bliska poznasz każdą rzecz statecznie" [Mieleszko 2010: 105].

Ponieważ temat, o którym mowa wyżej doczekał się w literaturze przedmiotu wnikliwego omówienia, dopowiedzmy, że luneta stała się w okresie baroku składnikiem symbolicznego imaginarium, którego arkana wyjaśniały popularne encyklopedie. Jest wśród nich, powstałe w latach zmierzchu epoki, sławne dzieło Benedykta Chmielowskiego Nowe Ateny (editio princeps: 1745-1746; poszerzone wydanie: 1754-1756). Prezentując „umbry

13 W powyższym akapicie relacjonuję wnioski z artykułu Jacka Kowzana [2014: 323-350]. Wśród egzemplifikacji źródłowych przedstawionych we wskazanym artykule wymienione są utwory Zbigniewa Morsztyna i Michała Mieleszki, których fragmenty przytaczam. 
objaśnione”, a pouczające „co w emblematach i symbolach [...] trzeba obserwować, aby nie były vitiosa", encyklopedysta wyjaśnit, że: „Adiectiva same nie służą na lemma, kładą jednak adverbia; na przykład nad perspektywą napisano: Procul et propere, dwie adverbia" [Chmielowski 2015: 81]. Co ciekawe, opracowując ten zapis, polski autor wykorzystał popularne kompendium emblematyki Filippo Picinellego Mondo simbolico (1653), w którym motto Procul et perspicue odnosi się do okularów, a nie do lunety [Chmielowski 2015:163-164, komentarz wydawców].

Skoro wyobraźnia artystów aplikowała motyw lunety do rozważań o rzeczach ostatecznych, nic dziwnego, że stosowała go również do spraw polityki, zwłaszcza, że ich domeny nie powinno oddzielać się od etyki religijnej. W tym duchu wojewoda ruski Jan Stanisław Jabłonowski napisał u schyłku życia traktat Skruput bez skruputu $w$ Polsce albo oświecenie grzechów narodowi naszemu polskiemu zwyczajniejszych, a za grzechy nie mianych (1730). Motyw lunety ( $w$ wersji znanej religijnej poezji baroku, łączącej jej używanie z działaniem diabła) został następująco wykorzystany pod piórem pisarza, który namysł nad osobistymi obywatelskimi przewinami łączył z próbą zbiorowego rachunku sumienia:

Aleć u mnie crescente infirmitate ciała mego, infirmitates duszy jaśniej pokazywać się poczęły i dlatego, abym uniknął strachu tego, co jeden moralista dowcipnie napisał, to jest, że diabeł przez cały wiek życia naszego oczom duszy i myśli naszej przyprawuje perspektywy, a to naprzód, żeby śmierć daleko się od nas być widziała, choć nie wiemy, że podczas bardzo blisko, a druga, żeby grzechy choćby największe, małe nam się widziały. Ale tenże nieprzyjaciel nasz czart przy samej śmierci już nie perspektywy, ale owe straszne szkła auktywa i większe czyniące rzeczy przyprawuje na umyśle i na oczach duszy naszej, przez które najmniejszy proszek górą całą być się zdaje, aby tym do zalęknienia i desperacji konających przywodził. Żeby mię tedy mówię, ta przestroga źle nie potkała i tych szkieł przemiana przy skonaniu i każdego, co to czytać będzie, chciałem zawczasu przy łasce i miłosierdziu Boskim przypomnieć sobie swoje i ludzkie ludziom grzechy i im się powoli 
przypatrywać, które diabeł w płaszczyki polityki, status, wolności, honorów, fortuny zwykł stroić jako na maskaradę [...]. [Jabłonowski 2013: 74]

7. W komediowej odsłonie: o obserwacjach „per tubum opticum, alias przez perspektywę"

Podążając za zafrapowanymi lunetą pisarzami baroku, zmienimy tonację rozważań, pozwalając, aby zabrzmiał w nich ton komediowy. Słyszymy go, gdyż znany i modny poza kręgami astronomów przyrząd naukowy bywał środkiem wywoływania komizmu i kreowania śmieszności postaci aspirujących do wyszukanej uczoności. Scena teatralna służyła temu znakomicie, a z właściwą sobie maestrią motyw lunety wyzyskał Molière w Uczonych białogłowach (1672). Niewieście pretensje do uczoności, obok zamiłowania do kartezjańskich wirów, teorii „drobnych ciałek” i innych dyskutowanych ówcześnie zagadnień naukowych, obejmują oczywiście pasję obserwowania nieba za pomocą nowoczesnego sprzętu. Pasja ta skutkuje ulokowaniem lunety na dachu domu pewnej sawantki, co jeden $\mathrm{z}$ bohaterów komedii podsumowuje tradycyjnie brzmiącym głosem zdrowego rozsądku:

Nieźle byłoby, sądzę, również ściągnąć z dachu Lunetę długą, przedmiot ludzkiego postrachu, Również sto innych figlów, co mieszkanie zdobi;

Nie podglądać co tam kto na księżycu robi,

A tym, co w domu słychać, zająć się czasami,

Gdzie wszystko dzisiaj chodzi do góry nogami.

Nie idzie to z pewnością nikomu na zdrowie,

Gdy żona kram z nauką zakłada w swej głowie [...].

[Molier 1988: 720-721]

Nie na dachu, lecz na ganku, znalazła się luneta w rękach obserwatora, którego miłosne perypetie przedstawił przywoływany już Lubomirski, tym razem jako autor Komedyji Lopesa starego ze Spiridonem, napisanej w latach siedemdziesiątych XVII stulecia. Sztuka ta to owoc „zabaw teatralnych” polskiego 
magnata, błyskotliwie wyzyskującego zasoby tak europejskiej, jak rodzimej tradycji teatralnej i literackiej, w tym twórczości satyrycznej i sowizdrzalskiej, której echa raz po raz pobrzmiewają w wypowiedziach bohaterów komedii ${ }^{14}$. Luneta, obok innych sprzętów składających się na instrumentarium astronomiczne pierwszej z postaci wymienionych w tytule, została przez Lubomirskiego sprawnie wykorzystana w tworzeniu humorystycznych efektów.

Jego sztuka dostarcza ich w obfitości, opowiadając o kłopotach posuniętego w latach Lopesa, który wziąwszy za żonę młodziutką Melisę, już w noc poślubną staje przed nie lada wyzwaniem: jak wymówić się od małżeńskiej powinności, skoro podeszły wiek na jej wypełnienie nie pozwala. Rozważając, co uczynić, „aby się dziś ustrzec consumationem" [Lubomirski 1963: 429], wpada na pomysł przekonania żony, że aby wejrzeć w czekającą ich małżeńską przyszłość, trzeba poznać, co na ten temat mówią gwiazdy. A ponieważ uchodzi nie tylko za filozofa czy jurystę, lecz i za astrologa, postanawia wmówić dziewczynie, że - choć trudno będzie mu pozostawić ją samą w sypialni - zadania tego podejmie się i konstelacji „będzie upatrował pilno per tubum opticum, alias przez perspektywę" [Lubomirski 1963: 429]. Przekonując ją do tego zamiaru, zapowiada, że uda się obserwować niebo, zbrojny tak w tradycyjne, jak nowoczesne urządzenia, „wziąwszy z sobą sfery, baculum Jacobi, astrolabium i perspektywę" [Lubomirski 1963: 429]. Zamysł zostaje wcielony w życie, a starzec, wylewnie żegnając połowicę, wzywa służącego - Biribisa, aby pomógł mu w obserwacjach, zwłaszcza w trzymaniu lunety. Dla precyzji oglądu nieba luneta jest niezbędna, lecz profesjonalne jej użycie nie jest proste, zwłaszcza, gdy obserwacje prowadzi się na mrozie, a asystuje przy nich niewprawny w tym względzie służący. Widzowie zgromadzeni w prywatnym teatrze Lubomirskiego w Ujazdowie, gdzie zapewne wystawiono Komedyję Lopesa, mogli przekonać się o tym, śledząc te oto poczynania bohaterów przedstawienia: 
Lopes: $\mathrm{Nu}$, Biribis, klęknij jeno tak spokojnie. Położę na tobie perspektywę, abym mógł lepiej dojźrzeć, przyklęknąwszy, płanety.

Biribis: Owo zaraz.

Lopes: $\mathrm{Nu}$, nie chwiejże się!

Biribis (drży od zimna) Dobrodzieju, umrę na miejscu! Diabła to ma być [elewacyja] na takim mrozie.

Lopes: Nu, weźże ołówka, a pisz, co-ć powiem. Będziesz mi notował gradus od gwiazdy do gwiazdy i aspekty, i opozycyje, które obaczę przez perspektywę. $\mathrm{Nu}$, stójże spokojnie! Spojźrzę teraz naprzód na Saturna, a potem na Wenerę.

Biribis: Wątpię, żeby się nam tej drugiej gwiazdy dostało widzieć.

Lopes (położywszy mu na głowie perspektywę): $\mathrm{Nu}$, nie chwiejże się! Anuż mi upadła perspektywa dla tego błazna!

Biribis: To to taka sprawa! Cóżem ja winien, że Waszmośc [i] nie chce stać? Bodajżem ja był służył u błazna w ciepłej izbie!

Lopes (znowu mu położywszy perspektywę na głowie): Teraz widzę!

Biribis: Co, przebóg?

Lopes: Widzę Saturna bardzo posępnego.

Biribis: Znać, że też to nie może, nieboraczek.

Lopes: Naterminujże: Saturnus in angulo gradu quadragesimo secundo.

Biribis: Zaraz, powoli! Owo li, już notavi. Nu, dalej.

Lopes: Więc teraz wejźrzę na Wenerę.

Biribis: A cóż po tym? Uciekliśmy od jednej, a mamy patrzać na drugą?

Lopes (patrzac): Teraz widzę, że Wenus jest in exaltatione. $\mathrm{Nu}$, piszże: i tyka się cingulum Orionis.

Biribis: Ba, pewnikiem! Podobno caudam Draconis. [Lubomirski 1963: 441-443] 
Komediopisarz nie poprzestał na obscenicznych konceptach, zbliżonych do tego, który widnieje w ostatniej kwestii przywołanej sceny. Gdy bowiem astrolog ogląda niebo przez lunetę, pozostawiona w sypialni żona staje się obiektem żywego zainteresowania młodego Spiridiona. Ten, przybywszy do domu nowożeńców, słyszy od pokojówki, że starego Lopesa „diabli wynieśli z perspektywą na ulicę" [Lubomirski 1963: 436]. Żywiołowy Spiridion przejmuje inicjatywę. Udaje się do sypialni Melisy, która - rozespana, acz miło zaskoczona - bierze roznamiętnionego młodzieńca za swego męża, w tej oto chwili uczynionego rogaczem. W ten sposób autor sztuki, wychodząc naprzeciw rozrywkowym upodobaniom teatralnej publiczności i nie unikając satyrycznych akcentów, upiekł dwie pieczenie przy jednym ogniu: dosadnie zadrwił z mariaży zawieranych przez leciwych mężczyzn z młodymi pannami, a nadto zakpił z astrologii. Sposób ukazania astrologa i uprawianej przezeń profesji - na pierwszy rzut oka zmodernizowanej, bo korzystającej z nowego instrumentarium astronomicznego jest na wskroś ludyczny, a luneta w rękach „gwiazdarza” wyostrza kontury śmieszności tej postaci.

Zamykając przegląd barokowych utworów, zauważmy, że dokumentacja powiązań historii literatury z historią nauki, skoncentrowana w tym studium na lunecie, dowodzi, iż powiązania te rzucają światło nie tylko na zakres wiedzy, jaką legitymowali się dawni twórcy - pisarze i uczeni - oraz na stosunek, jaki prezentowali wobec osiągnięć rewolucji naukowej. Jak się przekonaliśmy, ważny aspekt tych powiązań polega na tym, że podjęcie tematu lunety pomocne było $\mathrm{w}$ artykułowaniu zagadnień poznawczych, religijnych, moralnych i społecznych, określających ideową specyfikę kultury baroku. Jej obraz mogą wzbogacić - a być może uzupełnić o rysy dotąd nieznane - kolejne źródła mówiące o lunecie, dlatego ich wskazanie i omówienie jest intrygującym poznawczo zadaniem badawczym na przyszłość. 


\section{Bibliografia}

Backvis Claude (1993), Renesans i barok w Polsce. Studia o kulturze,

Wydawnictwo Naukowe PWN, Warszawa.

Bargieł Franciszek (1986), Wojciech Tylkowski i jego „Philosophia curiosa”

$z 1669$ r., Wydział Filozoficzny Towarzystwa Jezusowego, Kraków.

Barycz Henryk (1954), Dzieło literackie Jana Brożka, „Pamiętnik

Literacki” 1954, z. 1, s. 61-90.

Bacon Francis (1995), „Nowa Atlantyda” i $z$ „Wielkiej Odnowy”, przeł.

Wiktor Kornatowski, Jan Wikarjak, Wydawnictwo Afla, Warszawa.

Bennett James A. (2007), Teleskop w XVII wieku, w: Historia astronomii,

red. Michael Hoskin, przeł. Jarosław Włodarczyk, Wydawnictwo

Uniwersytetu Warszawskiego, Warszawa.

Bergerac Cyrano de (1956), Tamten świat, przeł. Julian Rogoziński,

Państwowy Instytut Wydawniczy, Warszawa.

Bieńkowska Barbara (1971), Kopernik i heliocentryzm w polskiej kulturze umystowej do końca XVIII wieku, Zakład Narodowy im. Ossolińskich, Wrocław.

Bieńkowski Tadeusz (1987), Polscy przedstawiciele „scientia curiosa”, „Rozprawy z Dziejów Oświaty” 1987, s. 5-34.

Bieńkowski Tadeusz, Jerzy Dobrzycki (1998), Staropolski świat nauki.

Uczeni i szkoly wobec osiagnięć nowożytnych nauk przyrodniczych, Instytut Historii Nauki PAN, Warszawa.

Birkowski Fabian (2012), Kazania o naukach tajemnych, oprac. Jerzy

Kroczak, Oficyna Wydawnicza Atut - Wrocławskie Wydawnictwo Oświatowe, Wrocław.

Brożek Jan (1956), Wybór pism, t. 1, oprac. Henryk Barycz, Państwowe Wydawnictwo Naukowe, Warszawa.

Bucciantini Massimo, Camerota Michele, Giudice Franco (2015),

Galileo's Telescope. A Eurepean Story, translated by Catherine

Bolton, Harvard University Press Cambridge, Massachusetts

[Stany Zjednoczone].

Bystrzonowski Wojciech (1749), Informacyja matematyczna rozumnie ciekawego Polaka, Lublin.

Curtius Ernst Robert (1997), Literatura europejska i łacińskie średniowiecze, przeł. Andrzej Borowski, Universitas, Kraków.

Chmielowski Benedykt (2015), Nowe Ateny, Umbry objaśnione, oprac. Jerzy Kroczak, Jacek Sokolski, Oficyna Wydawnicza Atut Wrocławskie Wydawnictwo Oświatowe, Wrocław.

Dacka-Górzyńska Iwona M., Partyka Joanna, red. (2009), Staropolskie kompendia wiedzy, Wydawnictwo DiG, Warszawa. 
Dobrzycki Jerzy (1998), Święty Jerzy gra na skrzypkach, czyli krakowski spór o podstawy i metodę nauki w XVII wieku, „Odrodzenie i Reformacja w Polsce" 1998, s. 73-80.

Drużbacka Elżbieta (2002), Wybór poezji, oprac. Jakub Niedźwiedź, Universitas, Kraków.

Dzienis Hanna (2011), Chluba Gdańska, w: Jan Heweliusz, red. Maria Pelczar, Jarosław Włodarczyk, Instytut Technologii Eksploatacji Państwowy Instytut Badawczy w Radomiu, Radom, s. 35-81.

Eco Umberto (2009), Szaleństwo katalogowania, przeł. Tomasz Kwiecień, Dom Wydawniczy Rebis, Poznań.

Fantoli Annibale (2002), Galileusz. Po stronie kopernikanizmu i po stronie Kościoła, przeł. Tadeusz Sierotowicz, Biblos, Tarnów.

Fontenelle [Bernard de] (1961), Rozmowy zmarlych, przel. Juliusz German, Czytelnik, Warszawa.

Galilei Galileo (1962), Dialog o dwu najważniejszych układach świata: Ptolemeuszowym i Kopernikowym, przeł. Edward Ligocki przy współudziale Krystyny Giustiniani-Kępińskiej, Państwowe Wydawnictwo Naukowe, Warszawa.

Galilei Galileo (2010), Sidereus nuncius, przeł. Artur Pacewicz, Oficyna Wydawnicza Atut - Wrocławskie Wydawnictwo Oświatowe, Wrocław.

Gostyńska Dorota (1991), Retoryka iluzji. Koncept w poezji barokowej, Instytut Badań Literackich PAN, Warszawa.

Hanusiewicz Mirosława (1998), Święte i zmysłowe w poezji religijnej polskiego baroku, Redakcja Wydawnictw KUL, Lublin.

Hanusiewicz Mirosława (2004), Pięć stopni miłości. O wyobraźni erotycznej w polskiej poezji barokowej, Semper, Warszawa.

Hayden Judy A., red. (2016), Literature in the Age of Celestial Discovery. From Copernicus to Flamsteed, Palgrave MacMillan, New York [Stany Zjednoczone].

Helden van Albert, Dupré Sven, Gent van Rob, Zuidervaart Huib, red. (2010), The Origins of the Telescope, knAw Press, Amsterdam [Holandia].

Heweliusz Jan (1977), Opis Księżyca, przeł. Tadeusz Włodarczyk, w: Filozofia i myśl spoteczna XVII wieku, t. 2, oprac. Zbigniew Ogonowski, Państwowe Wydawnictwo Naukowe, Warszawa, s. 176-186.

Jabłonowski Jan Stanisław (2013), Skrupuł bez skrupułu w Polsce, oprac. Bartosz Awianowicz, Jarosław Poraziński, Wydawnictwo Adam Marszałek, Toruń.

Jasiński Maciej (2013), The Inhabitants of the Moon in Hevelius's "Selenographia", w: Johannes Hevelius and His World. Astronomer, 
Cartographer, Philosopher and Correspondent, red. Richard

L. Kremer, Jarosław Włodarczyk, Instytut Historii Nauki PAN, Warsaw, s. 61-67.

Kochowski Wespazjan (1674), Niepróżnujące próżnowanie ojczystym rymem na lyrica i epigrammata polskie rozdzielone i wydane, Kraków.

Kochowski Wespazjan (1681), Ogród panieński pod sznur Pisma Świętego, doktorów kościelnych, kaznodziejów prawowiernych wymierzony, Kraków.

Kołos Anna (2015), Sceptycyzm w literaturze polskiego baroku, [online] praca doktorska WFPiK UAM Poznań, [dostęp: 27 stycznia 2017], http://hdl.handle.net/10593/13869.

Korczyński Adam (200o), Wizerunk złocistej przyjaźnią zdrady, wyd. Radosław Grześkowiak, Instytut Badań Literackich - Pro Cultura Litteraria, Warszawa.

Kotarski Edmund (1993), Gdańska poezja okolicznościowa XVII wieku, Wydawnictwa Instytutu Bałtyckiego, Gdańsk.

Kotarski Edmund (1987), „Hevelius Columbus coeli”, w: Kultura polska a kultura europejska. Prace ofiarowane Januszowi Tazbirowi w sześćdziesiątą rocznicę urodzin, red. Maria Bogucka, Jerzy Kowecki, Państwowe Wydawnictwo Naukowe, Warszawa, s. 170-188.

Kowzan Jacek (2014), Prudencja, luneta i rzeczy ostateczne. Wokót „Emblematu 96” Zbigniewa Morsztyna, „Terminus” 2014, z. 3, s. 323-35o.

Koyré Alexandre (1998), Od zamkniętego świata do nieskończonego wszechświata, przeł. Ola i Wojciech Kubińscy, słowo/obraz terytoria, Gdańsk.

Kuhn Thomas S. (2006), Przewrót kopernikański. Astronomia planetarna $w$ dziejach myśli Zachodu, przeł. Stefan Amsterdamski, Prószyński i S-ka, Warszawa.

Lisiak Bogdan (2005), Adam Adamandy Kochański (1631-170o). Studium $z$ dziejów filozofii i nauki w Polsce XVII wieku, Wydawnictwo WAM, Kraków.

Lovejoy Arthur O. (1999), Wielki łańcuch bytu. Studium z dziejów idei, przeł. ArturPrzybysławski, Wydawnictwo KR, Warszawa.

Lubomirski Stanisław Herakliusz (1963), Komedyja Lopesa, w: Dramaty staropolskie. Antologia, t. 5, oprac. Julian Lewański, Państwowy Instytut Wydawniczy, Warszawa.

Lubomirski Stanisław Herakliusz (1916), O znikomości rad, przeł. Antoni Marylski, Skład Główny Gebethner i Wolff, Warszawa.

Lubomirski Stanisław Herakliusz (2006), Rozmowy Artaksesa i Ewandra, wyd. Justyna Dąbkowska-Kujko, Instytut Badań Literackich Pro Cultura Litteraria, Warszawa. 
Malapert Karol (1633), Austriaca Sidera heliocyclia astronomicis hypotesibus illigata, Duaci [Douai].

Marino Giambattista, Anonim (1993), Adon, t. 1, wyd. Luigi Marinelli, Krzysztof Mrowcewicz, Tor Vergata, Wydawnictwo IBL, RomaWarszawa [Włochy- Polska].

Mendel Maria, Włodarski Józef, red. (2013), Jan Heweliusz i kultura heweliuszowska. „Utilitas et delectatio”, Wydawnictwo Uniwersytetu Gdańskiego, Gdańsk.

Mieleszko Mikołaj (2010), Emblematy, oprac. Radosław Grześkowiak, Jakub Niedźwiedź, Wydawnictwo Neriton, Warszawa.

Milton John (1986), Raj utracony, przeł. Maciej Słomczyński, Wydawnictwo Literackie, Kraków.

Molier (1988), Dzieła, t. 3, przeł. Tadeusz Żeleński (Boy), Państwowy Instytut Wydawniczy, Warszawa.

Morsztyn Zbigniew (2001), Emblemata, oprac. Janusz i Paulina Pelcowie, Wydawnictwo Neriton, Warszawa.

North John (1997), Historia astronomii i kosmologii, przeł. Tamara Dworak, Tadeusz Dworak, Książnica, Katowice.

Pomian Krzysztof (1996), Zbieracze i osobliwości. Paryż, Wenecja XVI-XVIII wiek, przeł. Andrzej Pieńkos, Państwowy Instytut Wydawniczy, Warszawa.

Przypkowski Tadeusz (1960), Astronomia w Kaliszu, w: Osiemnaście wieków Kalisza, t. 1, red. Aleksander Gieysztor, Wydawnictwo Poznańskie, Kalisz.

Przypkowski Tadeusz (1975), Astronomia $w$ Polsce w pierwszej połowie XVII wieku, w: Historia astronomii w Polsce, t. 1, red. Eugeniusz Rybka, Zakład Narodowy im. Ossolińskich, Wrocław.

Raubo Grzegorz (2011), „Ludzie się na górne zapatrują obroty”. Astronomiczne konteksty literatury polskiego baroku, Wydawnictwo Naukowe UAM, Poznań.

Roskal Zenon E. (2008), „Proteus caelestis” XVII-wiecznej astronomii, w: Oblicza filozofii XVII wieku, red. Stanisław Janeczek, Wydawnictwo KUL, Lublin, s. 407-422.

Rosa Mario (2001), Mniszka, przeł. Monika Gurgul, w zbiorze: Człowiek baroku, red. Rosario Villari, Volumen, Warszawa, s. 239-286.

Roszkowska Wanda (1971), Stanistawa Herakliusza Lubomirskiego „Lopes cum omnibus suis adiunctis”. Problemy rodzimej tradycji literackiej, w: O dawnym dramacie i teatrze. Studia do syntezy, red. Wanda Roszkowska, Zakład Narodowy im. Ossolińskich, Wrocław, S. 184-230. 
Roszkowska Wanda (1960), Włoski rodowód komedii S.H. Lubomirskiego,

Zakład Narodowy im. Ossolińskich, Wrocław.

Rybka Przemysław (1987), Instrumentarium astronomiczne Jana

Heweliusza (geneza i rozwój konstrukcji), Zakład Narodowy im.

Ossolińskich, Wrocław.

Shapin Steven (200o), Rewolucja naukowa, przeł. Stefan Amsterdamski,

Prószyński i S-ka, Warszawa.

Sierotowicz Tadeusz (2013), O położeniu plam słonecznych. Literatura, dialektyka, retoryka, filozofia $i$ astronomia $w$ „Istoria e dimonstrazioni intorno alle macchie solari" Galileusza wraz z tlumaczeniem dzieta, Biblos, Tarnów.

Smogulecki [Jan] Mikołaj (1626), Sol illustratus ac propognatus. Friburgi Brisgoviae.

Stownik polszczyzny XVI wieku (1967), t. 2, Zakład Narodowy

im. Ossolińskich, Wrocław.

Stownik polszczyzny Xvi wieku (1972), t. 6, Zakład Narodowy

im. Ossolińskich, Wrocław.

Stasiewicz Krystyna (2016), W kręgu polityki i literatury. Źródła i studia o Stanistawie Herakliuszu Lubomirskim, Pracownia Wydawnicza EIset, Olsztyn.

Stasiewicz Krystyna (2001), Zmystowa i elokwentna prowincjuszka na staropolskim Parnasie. Rzecz o Elżbiecie Drużbackiej i nie tylko..., Littera, Olsztyn.

Targosz Karolina (1975), Uczony dwór Ludwiki Marii Gonzagi (1646-1667). Z dziejów polsko-francuskich stosunków naukowych, Zakład Narodowy im. Ossolińskich, Wrocław.

Targosz Karolina (1979), Jan Heweliusz, uczony-artysta, Zakład

Narodowy im. Ossolińskich, Wrocław.

Targosz Karolina (1991), Jan III Sobieski mecenasem nauk i uczonych, Zakład Narodowy im. Ossolińskich, Wrocław.

Targosz Karolina (1997), Sawantki w Polsce XVII w. Aspiracje intelektualne kobiet ze środowisk dworskich, Retro-Art, Warszawa.

Targosz Karolina (2003), Polski wątek w życiu i sprawie Galileusza

„Galileo Galilei e il mondo polacco” Bronisława Bilińskiego (1969)

z uzupetnieniami, „Zagadnienia Filozoficzne w Nauce” 2003, s. 45-90.

Targosz Karolina (2011), Symbioza nauki i sztuki w dziele Jana Heweliusza,

w: Jan Heweliusz, red. Maria Pelczar, Jarosław Włodarczyk, Instytut Technologii Eksploatacji - Państwowy Instytut Badawczy w Radomiu, Radom, s. 97-165.

Tesauro Emmanuele (1999), Luneta Arystotelesowska, przeł. Wanda Nowicka, w: Źródła wiedzy teoretycznoliterackiej w dawnej Polsce. 
Średniowiecze - Renesans - Barok, oprac. Maria Cytowska, Tersesa

Michałowska, Wydawnictwo Naukowe PWN, Warszawa, s. 453-466.

Tylkowski Wojciech (1692), Uczone rozmowy wszystkę w sobie prawie zawierające filozofija, Warszawa.

Waniakowa Jadwiga (2003), Polska naukowa terminologia astronomiczna, Wydawnictwo Instytutu Języka Polskiego PAN, Kraków.

Witczak Agnieszka (2013), Iohannes Petrus Titius. Wiersze okolicznościowe dedykowane Heweliuszowi, w: Jan Heweliusz i kultura heweliuszowska. „Utilitas et delectatio”, red. Maria Mendel, Józef Włodarski, Wydawnictwo Uniwersytetu Gdańskiego, Gdańsk, s. 129-145.

Włodarczyk Jarosław (2005), Księżyc w nauce XVII wieku. Libracja: od astronomii do fizyki, Wydawnictwo Uniwersytetu Warszawskiego, Warszawa.

Włodarczyk Jarosław (2011), Księżyc Jana Heweliusza, w: Jan Heweliusz, red. Maria Pelczar, Jarosław Włodarczyk, Instytut Technologii Eksploatacji - Państwowy Instytut Badawczy w Radomiu, Radom.

Włodarczyk Jarosław (2012), Księżyc w nauce i kulturze Zachodu, Dom Wydawniczy Rebis, Poznań.

Wróblewski Andrzej (1980), Gwiazdy Medycejskie, „Kwartalnik Historii Nauki i Techniki” 1980, nr 3, s. 461-48o.

Zieliński Siegfried (2010), Archeologia mediów. O głębokim czasie technicznie zapośredniczonego słuchania $i$ widzenia, przeł. Krystyna Krzemieniowa, Oficyna Naukowa, Warszawa.

Zoomers Henk (2010), The Netherlands, Siam and the telescope. The first Asian encounter with a Dutch invention, w: The Origins of the Telescope, red. Albert van Helden, Sven Dupré, Rob van Gent, Huib Zuidervaart, KNAw Press, Amsterdam [Holandia], s. 301-320.

Żmudzka-Brodnicka Monika (2013), „Atlas uczonego świata” - o poezji ku czci Jana Heweliusza, w: Jan Heweliusz i kultura heweliuszowska. „Utilitas et delectatio", red. Maria Mendel, Józef Włodarski (2013), Wydawnictwo Uniwersytetu Gdańskiego, Gdańsk, s. 121-128.

Grzegorz Raubo

„Perspektywy gwiazdarskie” - „Stellar outlook” (transl.). Telescopes in the mainstream and academic literature of the Polish Baroque period The telescope played a crucial role in the modern scientific revolution and occupied a significant place in Baroque culture. Interest in the telescope has been confirmed by Polish literary sources and writings, including scientific treatises and compendia of knowledge. Telescopes are the subject of works on the popularization of science written in the scientia curiosa convention. 
Reflections on the telescope appear in the context of deliberations on the world system, on the possibility of the existence of life forms on the Moon and other celestial bodies, and in the context of polemic against Aristotelian cosmology.

The telescope is an element of religious deliberations concerning eschatology and those focused on astronomy, whose aspiration to get to know the universe is motivated by secular curiosity. The matter of conducting observations of the sky with the use of the telescope has turned into a comedy show, in a satirical way relating to the practice of astrology.

Keywords: scientific revolution, the history of astronomy, the telescope, Polish literature, the popularization of science, academic literature

Grzegorz Raubo - prof. zw. dr hab., pracownik Instytutu Filologii Polskiej UAM, członek zespołu redakcyjnego półrocznika „Poznańskie Studia Polonistyczne. Seria Literacka”. Jego zainteresowania dotyczą historii idei w epoce baroku, związków literatury z historią nauki (głównie astronomii) oraz filozoficznych aspektów literatury. Jest autorem książek: Barokowy świat człowieka. Refleksja antropologiczna w twórczości Stanistawa Herakliusza Lubomirskiego (1997), Światto przyrodzone. Rozum w literaturze polskiego baroku (2006), „Ludzie się na górne zapatrują obroty”. Astronomiczne konteksty literatury polskiego baroku (2011), Kalendarze, kurioza i rzeczy ostateczne. Z zagadnień literatury popularnej w dawnej Polsce (2011).E-mail: graubo@amu.edu.pl. 
